\title{
ANALISIS ANGGARAN PELAKSANAAN PEMILIHAN WALIKOTA SOLOK PADA PILKADA SERENTAK NASIONAL TAHUN 2015
}

\section{BUDGET ANALYSIS OF THE SOLOK MAYOR ELECTION IN THE 2015 NATIONAL SIMULTANEOUS ELECTION}

\author{
Hendri Koeswara ${ }^{1}$, Ira Irawati ${ }^{2}$, dan Arry Bainus ${ }^{2}$ \\ Program Doktoral Administrasi Publik pada Universitas Padjadjaran ${ }^{1}$ \\ Fakultas IImu Sosial dan IImu Politik Universitas Padjadjaran ${ }^{2}$ \\ JI. Jln. Raya Bandung-Sumedang Km. 21, jawa Barat \\ e-mail : hendrikoeswara@soc.unand.ac.id
}

Naskah diterima: 6 Agustus 2018; revisi terakhir: 1 Oktober 2018; disetujui: 8 November 2018

\begin{abstract}
The Solok Mayor Election was one of the simultaneous Election of Regional Heads held on the first wave of national elections along with 269 regions in Indonesia and simultaneously with the Governor Election and 13 Regents/Mayors in West Sumatera Province. Not only the simultaneous implementation of Pilkada but the joint funding was initiated to reduce the burden of the regional budget. The research which aims to explain the process of budgeting of Solok Mayor Election in the first wave regional elections in year 2015. Using qualitative research method with a case study approach, this study concludes that the Solok Mayor Election budget has been based on the principles in the budget preparation stage and formulation in the budget cycle. Turbulence policy on the implementation of the election model in the Election of Regional Heads is anticipated with policy anticipation both in terms of planning and budgeting that it doeas not disrupt the regional budget cycle. But on the other hand, there is no proportional joint funding (cost sharing) according to the workload among the executors of the Simultanoeus Regional Head Election that it makes the budget for the Election of Regional Heads burden for the Solok City Regional Revenue Budget.
\end{abstract}

Keywords: Budgeting, budget, simultaneously local elections. 


\begin{abstract}
Abstrak
Tulisan ini tentang analisis anggaran pelaksanaan Pemilihan Walikota Solok Tahun 2015yang termasuk dalam Pilkada serentak nasional gelombang pertama di Indonesia bersama 269 daerah dan serentak dengan Pemilihan Gubernur serta 13 Bupati/Walikota di Provinsi Sumatera Barat. Tidak saja pelaksanaan Pilkada yang serentak tetapi pendanaan bersama kembali digagas untuk mengurangi beban anggaran daerah. Riset yang bertujuan untuk menjelaskan proses penganggaran Pemilihan Walikota Solok pada Pilkada Serentak Nasional Gelombang Pertama pada Tahun 2015 yang lalu. Tulisan ini menggunakan metode penelitian kualitatif dengan pendekatan studi kasus dalam penelitian. Sehingga dapat disimpulkan bahwa anggaran Pemilihan Walikota Solok telah berdasarkan pada prinsip-prinsip dalam tahapan budget preparation and formulation dalam siklus anggaran. Turbulensi kebijakan tentang pelaksanaan model pemilihan dalam Pilkada diantisipasi dengan kesiapan kebijakan (policy anticipation) baik dari sisi perencanaan maupun anggaran sehingga tidak mengganggu siklus anggaran daerah. Tapi, disisi lain tidak terjadi pendanaan bersama yang proporsional (cost sharing) sesuai beban kerja diantara pelaksana Pilkada serentak sehingga menjadikan anggaran Pilkada beban bagi APBD Kota Solok.
\end{abstract}

Kata Kunci: Penganggaran, anggaran, Pilkada serentak.

\title{
A. PENDAhULUAN
}

Terdapat dua kesimpulan utama berdasarkan hasil audit BPK dalam kaitannya dengan persiapan Pilkada serentak secara nasional Gelombang I (pertama) pada Tahun 2015 yang lalu. Pertama; adalah belum diyakininya ketersediaan anggaran untuk mendukung seluruh penyelenggaraan Pilkada 2015, dan yang kedua; belum diyakininya ketersediaan Sumber Daya Manusia termasuk aspek kelembagaan atau infrastruktur pendukungnya. Akan tetapi, pemerintah dan KPU justru menyatakan sebaliknya bahwa mereka telah siap untuk melaksanakan pilkada serentak nasional tersebut walaupun masih terdapat beberapa kendala yang dihadapi. Menurut BPK hasil audit yang dilaksanakan pada Tanggal 8 Juni sampai dengan 13 Juli Tahun 2015 itu merupakan hasil evaluasi dan bukan memberikan kesimpulan bahwa KPU tidak siap melakukan Pilkada (Sanur L, 2015). Pilkada Kota Solok termasuk sebagai Pilkada serentak nasional gelombang I (Pertama) yang dilaksanakan pada Tanggal 9 Desember 2015 bersamaan dengan 269 (Dua ratus enam puluh sembilan) daerah lainnya di Indonesia. Akan tetapi, Pilkada serentak Tahun 2015 ini bukanlah Pilkada serentak yang dilakukan pertama kali di Provinsi Sumatera Barat, karena pada Tahun 2010 yang lalu Kota Solok dan Provinsi Sumatera Barat juga sudah pernah melakukan Pilkada serentak dengan dilaksanakannya Pemilihan Gubernur dan 13 (tiga belas) Pemilihan Bupati/Walikota di Provinsi ini. Artinya, dari dulu sudah terdapat semangat atau upaya untuk melakukan penghematan anggaran yang dilaksanakan melalui Pilkada serentak di Provinsi Sumatera Barat.

Pada Pilkada Tahun 2010 yang lalu, biaya yang dibutuhkan untuk satu orang pemilih (unit cost) Pilkada Kota Solok jauh lebih tinggi dibandingkan dengan unit cost Pilkada Provinsi Sumatera Barat yaitu sebesar Rp. 127.245 berbanding Rp. 22.000. Unit cost Pilkada 
Kota Solok juga sangat tinggi jika dibandingkan dengan unit cost Pilkada kab/kota dan provinsi lain yang melaksanakan Pilkada pada Tahun 2010 ketika itu. Bahkan, unit cost yang dibutuhkan untuk satu orang pemilih di Kota Solok ini juga sangat tinggi jika dibandingkan unit cost Pemilihan Umum Presiden (Pilpres) 2009 yang hanya sebesar Rp. 39.000, sehingga dianggap pemborosan anggaran dalam melaksanakan Pilkada serentak (Seknas Fitra, 2011). Pilkada 2015 di Kota Solok mempunyai unit cost yang tinggi yaitu sebesar Rp. 107.795. Hal tersebut masih lebih tinggi daripada unit cost Pemilihan Gubernur dan Wakil Gubernur Provinsi Sumatera Barat yang hanya sebesar Rp. 22.285, dimana hal tersebut tidak terlalu jauh berbeda dengan unit cost pada Pilkada Tahun 2010 silam.

Pemerintahan Daerah selalu dihadapkan pada keterbatasan ruang fiskal yang membuat terbatasnya pendanaan bagi daerah untuk alokasi pelbagai kebutuhan belanja maupun pembiayaan daerah. Hal tersebut ditambah lagi dengan beban dana penyelenggaraan Pilkada bersumber dari Anggaran Pendapatan dan Belanja Daerah (APBD). Terkait dengan sumber pendanaan Pilkada dari APBD hal tersebut diatur melalui Undang-Undang (UU) Nomor 8 Tahun 2015 tentang Perubahan atas UU Nomor 1 Tahun 2015 tentang Penetapan Peraturan Pemerintah Pengganti Undang-Undang (Perppu) Nomor 1 Tahun 2014 tentang Pemilihan Gubernur, Bupati, dan Walikota menjadi Undang-Undang bahwa pendanaan kegiatan pemilihan pemilihan gubernur dan wakil gubernur, bupati dan wakil bupati, serta wali kota dan wakil walikota dibebankan pada Anggaran Pendapatan dan Belanja Daerah. Artinya, kebijakan tentang pendanaan Pilkada ini telah memberikan kepastian bahwa anggaran Pilkada masih dianggarkan melalui APBD oleh daerah yang akan melaksanakan pesta demokrasi lokal tersebut. Padahal APBD dari sisi pendapatan masih memiliki ketergantungan terhadap dana perimbangan dari pusat. Tidak saja mempengaruhi komposisi pendapatan daerah, belanja Pilkada juga mempengaruhi komposisi belanja daerah seperti belanja hibah yang terjadi pada Pilkada Kota Solok.

Lemahnya kemampuan aktor anggaran dalam proses penganggaran juga menjadi penyebab terjadinya overfinancing, yang akan mempengaruhi anggaran yang dihasilkan. Sejatinya perkembangan teori anggaran tidak lepas dari Teori Administrasi Publik dan Teori Organisasi. Gibran dan Sekwat (2009) menyatakan perkembangan teori anggaran selama ini hanyalah proses mekanikal yang hanya mengalokasikan sejumlah uang, tanpa memperhatikan pertanyaan normatif dan nilai-nilai sosial politik yang melingkupinya. Teori anggaran yang ada selama ini belum memuaskan dan masih memerlukan pendekatan alternatif karena dianggap belum sempurna (heuristic). Para pemikir Administrasi Publik berhasil menunjukkan masalah-masalah ketidakefisienan dan efektivitas operasional pemerintahan di bidang anggaran dengan menggunakan instrument-instrumen yang dibangun atas rasionalitas teknis (Indrayeni, 2013).

Secara konseptual anggaran merupakan pernyataan mengenai estimasi kinerja yang hendak dicapai selama periode waktu tertentu yang dinyatakan dalam ukuran finansial. Atau merunut pada pendapat Lee Jr., Johnson dan Joyce (2013) " a budget is a document or a collection of documents that refers to the financial condition and future plans of an organization (family, corporation, government), including information on revenues, expenditures, activities, and purposes or goals". Bastian (2010) mendefinisikan anggaran sebagai rencana operasi keuangan, yang mencakup estimasi pengeluaran yang diusulkan, dan sumber pendapatan yang diharapkan untuk membiayainya dalam periode tertentu. Sementara Suparmoko (2003) menyatakan bahwa anggaran ialah suatu daftar atau pernyataan yang terperinci tentang penerimaan dan pengeluaran negara yang diharapkan dalam jangka waktu tertentu, yang biasanya adalah satu tahun. Alat utama kebijakan fiskal adalah anggaran yang 
oleh pemerintah digunakan untuk mengarahkan perkembangan sosial dan ekonomi, menjamin kesinambungan, dan kualitas hidup masyarakat. Anggaran sektor publik penting karena anggaran sektor publik mempunyai beberapa fungsi utama sebagaimana yang diungkapkan oleh Mardiasmo (2004), yaitu; (1) Sebagai alat perencanaan (planning tool); (2) Alat pengendali (controll tool); (3) Alat kebijakan Fiskal (Fiscal tool); (4) Alat politik (political tool); (5) Alat koordinasi dan komunikasi (coordination dan communication tool); (6) Alat penilaian kinerja (performance measurement tool); (7) Alat motivasi (motivation tool; dan (8) Alat menciptakan ruang publik (public sphere).

Penganggaran itu sendiri adalah proses atau metode untuk mempersiapkan suatu anggaran (Mardiasmo, 2009). Dalam konteks inilah penganggaran merupakan upaya untuk mempersiapkan anggaran yang dibutuhkan termasuk dalam hal ini anggaran Pilkada. Sementara itu, Gibran dan Sekwat (2009) memberikan pandangan tentang penganggaran yaitu "Budgeting is the most central activity of government and it affects all aspects of government action in a most profound manner. Thus, it could be considered to be at the technical core of government activities". Pendapat lain tentang penganggaran publik dikemukakan Reed dan Swain (1997) yaitu "public budgeting can be defined as the planned acquisition and use of resources by public entities, similar to what individuals and households do when making and spending money". Lalu, beliau menambahkan bahwa "Budgeting proposal and results are recorded in documents that are plans for gathering and spending moner over some time period"'(Reed dan Swain, 1997), artinya bahwa proses penganggaran tersebut menghasilkan proposal atau dokumen anggaran yang mencatat tentang pemasukan dan pengeluaran dalam satu periode atau waktu tertentu. Sedangkan dari perspektif pembuat kebijakan penganggaran ini merupakan "Decisions on revenues and expenditures to meet constituen concerns" (Reed dan Swain, 1997).

Penganggaran dianggap sebagai isu sentral karena bersifat prospective atau anticipatory sehingga aktor yang terlibat dalam penganggaran tidak saja harus mengetahui tentang sistem penganggaran yang berlaku, tetapi yang tak kalah pentingnya adalah memahami prinsip-prinsip pokok yang ada dalam siklus anggaran yang digunakan dalam praktek penganggaran. Sementara itu, kinerja anggaran mempunyai peran yang teramat penting dalam siklus anggaran sebagaimana yang diungkap oleh Shah dan Shen dalam Shah(ed) (2007) bahwa "Performance measurement plays an important role in the budget cycle", sehingga penganggaran yang baik dalam hal kinerja akan selalu dilihat dari perspektif siklus anggaran yang dilakukan. Penganggaran merupakan sebuah proses yang berulang dalam sebuah siklus sehingga ketika membicarakan tentang penganggaran maka tidak akan lepas dari tahapan-tahapan dalam siklus anggaran itu sendiri, hal tersebut sebagaimana seperti yang dikemukakan oleh Mikessel dalam Shah(ed) (2007) bahwa: "Budgeting itself is recurring cycle in which (a) the chief executive of government, with operating agencies, develops a service plan to respons to conditions anticipated in the upcoming year; (b) the approriate legislative body reviews that plan and adopts a program response based on that plan; (c) th administration puts the adopted program into effect; (d) an external review body audits and evaluates the executed program and reports its findings to the legislative body and citizenry”.

Banyak ahli yang mengemukakan fase-fase yang terdapat dalam siklus anggaran, dan pada umumnya yang terdiri dari empat tahap yaitu; (1) Tahap persiapan anggaran; (2) Tahap ratifikasi; (3) Tahap implementasi; dan (4) Tahap pelaporan atau evaluasi. (Bastian, 2009). Berbeda dengan ahli lainnya yang menggunakan istilah budget cycle dalam penganggaran, Rosenbloom dan Kravchuck (2005) menggunakan istilah stages in budgetary process. 
Menurut ahli ini proses penganggaran pada pemerintah bisa dipisahkan ke dalam 5 (lima) tahapan, yaitu:State government budget processes more or less follow this process as well: (1) Formulation of individual agencies budgets; (2) Preparation of the executive budget by the central budget agency (OMB), in consultation with the president and/or his advisers; (3) Presentation of the budget to the legislature; (4) Legislative action on the proposed budget and enactment of legislation approptiating funds; and (5) Execution of the budget by the executive branch.

Pendapat lain dikemukakan oleh Reed dan Swain (1997) bahwa proses penganggaran publik dapat digambarkan dalam empat tahapan, tetapi ahli ini juga mempunyai penamaan yang berbeda untuk tiap siklusnya, yaitu: (1) Preparation or formulation; (2) Submission and approval, policy making, legal enactment, or formal approval; (3) Implementation or execution; (4) Audit and review, audit and evaluation, or review. Begitupun dengan Anderson (2006) bahwa proses penganggaran dibagi atas empat tahapan, seperti pendapat beliau, yaitu "the national budgetary process, as well as state local budgetary process, can be devide into four fairly distint stages: (1) Preparation; (2) Authorization; (30 Execution; dan (4) Audit". Sedangkan siklus anggaran menurut Lee Jr., Johnson dan Joyce (2013) adalah aktivitas penganggaran yang dapat dilukiskan sebagai sebuah siklus yang terdiri atas empat tahapan yaitu Preparation and submission; Approval; Execution; dan Audit and evaluation. Lebih lengkapnya seperti yang dikemukan oleh Lee Jr., Johnson dan Joyce (2013) mengungkapkan bahwa: "The discrete activities that constitute budgeting are geared to a cycle. The cycle provides the timetable for the system to absorb and respon to a new information and, therefore, allows government to be held accountable for its action. Although existing budget systems may be less than perfect in guaranteeing adherence to this principle of responsibility, periodicity contributes to achieving and maintaining limited government. The budget cycle consist of four phases: (1) preparation and submission, (2) approval, (3) execution, and (4) audit and evaluation".

Sementara Prawoto (2011) menyebutkan siklus anggaran pada praktek penganggaran yang terjadi dalam siklus APBN mempunyi lima fase yaitu: (1) Budget preparation, persiapan oleh eksekutif/pemerintah dan perangkat-perangkatnya. Tahap ini meliputi dua kegiatan yaitu perencanaan dan penganggaran; (2) Legislative enactment, persetujuan legislatif (DPR); (3) Budget execution, pelaksanaan APBN; (4) Financial reporting, laporan akhir tahun oleh eksekutif (pemerintah) kepada legislatif (DPR); (5) Auditing, merupakan tahap akhir dari siklus APBN, dimana realisasi APBN diaudit oleh BPK. Sementara pendapat lainnya, seperti yang dikemukakan oleh Mullins dalam Shah(ed) (2007) bahwa "any government budget process entails a cycle: preparation and formulation; approval; execution; and audit and evaluation".

Tahapan atau fase awal dalam siklus anggaran dari masing-masing pendapat para ahli mempunyai penamaan yang berbeda, sebagian menyebut sebagai persiapan sebagian lainnya menyebut perencanaan. Tapi, ada satu hal yang pasti bahwa pada fase awal inilah dokumen anggaran dihasilkan dan pemerintah mempunyai peranan penting dalam proses awal penganggaran tersebut sebagaimana yang dikemukakan oleh Mullins tentang urgensi proses awal dalam siklus anggaran bahwa "preparation is often viewed as predominantly an executive role and includes the planning (sometimes referred to as pre-preparation) and the linkage of plans through a medium-term fiscal framework to a medium-term expenditure framework for the annual budget, establishment of priorities and resource and spending envelopes, instructions for agency budget submissions, and administrative review of the budget request." Lalu, beliau menambahkan argumentasinya tentang pentingnya proses awal penganggaran dalam menghasilkan dokumen anggaran, sebagaimana yang beliau ungkapkan 
bahwa "process issues permeate all elements of the budget cycle. However, the process is most identified with the rules and procedures and inputs and timetables of actor involvement in budget formulation and approval stages. Within these two stages, budgetary choices take shale and are finalized in an official government budget (Mullins dalam Shah(ed), 2007)". Dalam konteks inilah penganggaran terutama pada tahapan budget formulation dan approval stage menjadi sisi yang sangat penting dalam siklus anggaran, karena pada tahapan inilah anggaran dirumuskan dan dilakukan finalisasi serta kemudian ditetapkan. Penulis menggunakan pendapat ahli tersebut dalam penelitian yang dilakukan ini untuk melihat penganggaran Pilkada di Kota Solok melalui dua tahapan yang paling krusial dimana anggaran tersebut dipertajam dan difinalisasi serta ditetapkan sebagai dokumen anggaran yang resmi yaitu pada tahapan budget preparation and formulation yang dapat diuraikan menjadi; policy guidance and outlook, instruction and expenditure standard, dan review and compilation dan Legislative Review and Approval yang terdiri dari budget coverage, review, dan scope of approval (Mullins dalam Shah(ed), 2007).

Kemampuan pemerintah daerah dalam penganggaran serta pelaksanaan Pilkada termasuk isu strategis yang mesti disikapi secara bijak. Banyak penelitian tentang anggaran tapi masih sedikit kajian yang dilakukan tentang penganggaran penyelenggaraan Pilkada. Kajian penelitian tentang anggaran yang pernah dilakukan, misalnya penelitian yang dilakukan oleh Hough (1994), Fanloni (2006), Heivilin (1987), Hanida dkk (2011), Hermawan (2013) yang fokus pada proses penganggaran dalam menyusun APBD dan mengukur kinerja pemerintah daerah dalam penetapan program serta pengalokasian belanja daerah di dalam setiap siklus anggaran. Kajian ini berbeda dengan yang dilakukan oleh Zaltsman (2008) yang fungsi monitor dan evaluasi saja dalam siklus anggaran. Penelitian yang mengkaji tentang anggaran yang hanya fokus pada proses penyusunan juga telah banyak dilakukan, seperti kajian oleh Heru S. (2004), Henandarto (2009), dan Ristanto (2011) yang mengaitkannya dengan anggaran kinerja. Lain halnya dengan Hisyam (2012) dan Kestari (2011) yang lebih menitikberatkan kajiannya pada bagaimana perilaku aktor yang terlibat dalam penganggaran. Hal tersebut juga berbeda dengan penelitian yang dilakukan oleh Djafar (2006), Yani (2010), Manapode (2012), Makhya (2012) dan Hoiri (2014), mereka mengkaji proses penganggaran dari perspektif proses kebijakan publik.

Sementara penelitian yang mengaitkan penganggaran dengan pelaksanaan Pemihan Umum (Pemilu) juga telah banyak dilakukan oleh para ahli, seperti Vergne (2009) yang mengungkapkan bahwa sebelum Pemilu, anggaran belanja publik meningkat, sementara pendapatan pemerintah menurun, sehingga anggaran pada tahun pelaksanaan Pemilu defisit. Hal ini diharapkan akan memberikan dampak pada perolehan suara karena mempengaruhi Pemilih karena peningkatan belanja publik dan penurunan pajak. Kajian serupa tentang kaitan pengalokasian anggaran dan pelaksanaan Pemilu juga pernah ditulis oleh Candel-Sanchez (2007), Drazen dan Eslava (2010), Economides, Philippoulus, dan Price (2003), Kim dan Kwon (2014), dan tentunya hasil kajian yang dilakukan oleh Rogoff (1990) yang banyak menginspirasi penelitian yang mengaitkan proses penganggaran dan Pemilu yang menitikberatkan perilaku aktor yang terlibat dalam penganggaran dalam mempengaruhi publik melalui instrumen anggaran agar terpilih kembali.

Sedangkan penelitian tentang anggaran Pilkada yang pernah dilakukan salah satunya adalah penelitian yang dilakukan oleh Seknas Fitra dan TAF (2010) yang meneliti di 14 wilayah provinsi/kabupaten/kota di Indonesia tentang analisis anggaran Pilkada yang memberikan peluang yang besar bagi aktor di daerah untuk melakukan proses politik dan politisasi anggaran. Penelitian tentang anggaran Pilkada ini, baru sebatas bagaimana petahana 
mempengaruhi besaran APBD pada tahun Pilkada untuk kepentingan politik. Sedangkan penelitian Koeswara, Liesmana, Hanida, dan Muluk (2011) yang juga melakukan analisis terhadap komparasi kebutuhan anggaran Pilkada di Kabupaten Bandung dan Kota Solok pada Tahun 2010, tetapi belum pada masa Pilkada serentak nasional dan menggunakan pendekatan kebijakan publik.

Untuk itu, kajian yang penulis lakukan ini untuk melihat seperti apa pelaksanaan penganggaran Pilkada Tahun 2015 dengan adanya Pilkada serentak di Indonesia gelombang I (pertama), apakah terdapat pembagian beban kerja yang berimplikasi pada anggaran yang lebih proporsional sebagaimana halnya yang merupakan tujuan diadakannya Pilkada serentak ini yang berujung pada akuntabilitas anggaran Pilkada itu sendiri. Kontribusi dari hasil penelitian tentang bagaimana penganggaran pelaksanaan Pilkada dibuat yang mampu menghasilkan pemimpin yang diharapkan di daerah tapi dari sisi anggaran pelaksanaan lebih hemat dengan adanya Pilkada serentak ini baru sedikit dilakukan. Pembahasan anggaran sangat teknokratik dan sarat muatan politik sehingga menjadikan anggaran sebagai refleksi dari pilihan-pilihan pengalokasian yang mesti diputuskan oleh pemerintah sebagaimana yang diungkapkan oleh Rubin (2000) bahwa "budget reflect choices about government will and will not do. They reflect general public consensus about what kinds of services that governments should provide and what citizens are entitled to as members of society", termasuk juga pengalokasian anggaran Pilkada. Tulisan tentang anggaran Pilkada ini tidak untuk memunculkan berbagai tuntutan baru atas nama rakyat, akan tetapi harus dipandang sebagai sebuah kajian yang menyeluruh agar kemudian terbangun sebuah informasi yang sistematis dari berbagai aspek dan model penganggaran Pilkada yang baik agar dapat memberikan pemahaman yang lebih baik dan memiliki manfaat yang lebih besar untuk publik. Berdasarkan fenomena dan kompleksitas penganggaran Pilkada tersebut menarik untuk dilakukan kajian lebih jauh dalam upaya menemukan model penganggaran Pilkada yang lebih baik yang menghasilkan anggaran yang lebih efisien dan akuntabel sehingga tidak membebani keuangan daerah. Untuk itu, tulisan ini untuk menjawab pertanyaan persoalan tentang "Bagaimana pelaksanaan penganggaran Pemilihan Umum Kepala Daerah secara Langsung Tahun 2015 di Kota Solok Provinsi Sumatera Barat?”

\section{B. METODE PENELITIAN}

Metode penelitian dalam kajian ini menggunakan metode penelitian kualitatif sebagaimana yang diungkapkan oleh Cresswell (2013) untuk mengungkap persoalan terkait proses penganggaran pelaksanaan Pemilihan Walikota Kota Solok pada Tahun 2015 yang merupakan Pilkada serentak nasional gelombang pertama yang dilakukan secara nasional, dimana anggarannya tidak proporsional secara beban kerja sehingga tidak efisien dan berujung pada tidak akuntabelnya anggaran pelaksanaan Pilkada di Kota Solok tersebut.

Pendekatan penelitian kualitatif, dimulai dengan penggunaan teori sebagai kerangka kerja atau kerangka pikir, tapi teori tidak menjadi pembimbing utama dalam rancangan penelitian dan tidak menjadi alat utama untuk menafsirkan data penelitian yang didapatkan dari kajian yang dilakukan (Cresswell, 2013). Sedangkan pendekatan yang digunakan dalam penelitian kualitatif ini penulis memilih pendekatan case study. Teknik pengumpulan data dilakukan melalui wawancara mendalam untuk mendapatkan data primer dengan aktor yang terlibat langsung dalam proses penganggaran Pilkada di Kota Solok dan mengetahui kebijakan terkait anggaran Pilkada sebanyak 12 orang yang terdiri dari KPU Kota Solok, DPRD Kota Solok, TAPD Kota Solok, KPU Provinsi Sumatera Barat, KPU RI dan Kementerian Dalam Negeri. Dan dilengkapi dengan observasi terhadap proses penganggaran 
Pilkada Kota Solok pada Tahun 2015 yang lalu, serta pengumpulan data sekunder yang relevan yang terdiri dari dokumen anggaran Pilkada Kota Solok dan kebijakan terkait Pilkada dan Anggaran Pilkada.

Analisis data dalam penelitian kualitatif terdiri dari menyiapkan dan mengorganisir data (diantaranya transkrip, atau data gambar seperti grafik dan lain-lain) untuk dianalisis. Dalam penelitian ini, penulis fokus pada analisis proses penganggaran Pilkada Kota Solok Tahun 2015 dengan melakukan interpretasi data dan memberikan makna terhadap apa yang menjadi pusat perhatian (Creswell, 2013), yaitu anggaran pelaksanaan Pilkada serentak nasional gelombang I (pertama) tersebut. Artinya, dalam penelitian ini, penulis mengolah data dengan memberikan kategori, mensistematisasi, bahkan memproduksi makna oleh penulis sendiri terhadap apa yang menjadi pusat perhatian.

\section{KERANGKA TEORI}

Kapabilitas dan efektivitas pemerintah dalam proses penganggaran masih terlalu lemah. Kondisi yang ada saat ini, masih banyak lembaga pemerintah belum menjalankan fungsi dan perannya secara efisien. Pemborosan adalah fenomena umum yang terjadi akibat lemahnya kemampuan pemerintah dalam bidang anggaran yang memungkinkan munculnya underfinancing atau overfinancing sehingga mempengaruhi tingkat efisiensi dan efektivitas anggaran yang tidak sesuai lagi dengan tuntutan rakyat saat ini yang memerlukan akuntabilitas publik yang tinggi. Proses perencanaan anggaran Pilkada yang sumber anggaran juga juga berasal dari dana publik mestinya merupakan representasi dari keinginan rakyat dan meningkatkan kualitas pelaksanaan Pilkada itu sendiri. Dalam kajian anggaran pelaksanaan Pemilihan Walikota Solok pada Pilkada serentak nasional Tahun 2015 ini, peneliti menggunakan pendapat Mullins dalam Shah(ed) (2007) yang menjelaskan bagaimana penganggaran dilakukan mulai dari fase Budget Preparation and Formulation dilakukan sampai anggaran ditetapkan melalui tahapan Legislative Review and Approval agar anggaran yang dihasilkan menjadi lebih efektif, dan efisien serta akuntabel. Mullins dalam Shah(ed) (2007) juga mengemukakan bahwa process issues permeate all elements of the budget cycle. However, the process is most identified with the rules and procedures and inputs and timetables of actor involvement in budget formulation and approval stages. Within these two stages, budgetary choices take shale and are finalized in an official government budget. Berdasarkan pandangan ahli inilah penganggaran pilkada di Kota Solok yang dilaksanakan pada Tahun 2015 yang lalu, akan dilihat dari dua langkah yang dikemukakan oleh Mullins tadi yaitu: pertama, Budget Preparation and Formulation; kedua, Legislative Review and Approval agar anggaran Pilkada tersebut menjadi efektif dan efisien serta akuntabel.

Terdapat beberapa langkah dalam menyiapkan dokumen anggaran yang merupakan produk dari perencanaan anggaran. Dalam budget preparation and formulation atau persiapan dan formulasi anggaran menurut Mullins dalam Shah(ed) (2007), mengemukakan beberapa tahapan dalam fase pertama dalam budget cycle tersebut, yaitu; policy guidance and outlook, instruction and expenditure standard, dan review and compilation, untuk lebih lengkap penjelasan tentang tahapan yang terdapat dalam fase pertama ini sebagai berikut:

1. Policy guidance and outlook, Effective budget development requires establishment of expenditure priorities. This process begins in a planning or preplanning stage and is often dominated by executive actors. Information flows are both top down and bottom up. In more ideal systems, policy guidance is given in a top-down process through establishment of expectations and parameters for budget development. These expectations and 
parameters take the form of directives to agencies and spending divisions from the executive administration.

2. Instruction and expenditure standards, Budget instructions should identify programmatic priorities, the fiscal environment (restraint, retrenchment, expectations for budget reduction, threshold limitations on requests, and constraints), executive receptivity (or lack thereof) to spending initiatives, assumptions for cost increases (for critical inputs), expectations for personnel allocations, and information required for budget requests. In addition, instructions should specify the form that spending submissions should take, the type of justification required for continued and new spending initiatives, and the timetable for submission. The timetable should identify the dates when detailed submissions are to be made, submissions will be reviewed, and administrative hearings and appeals will occur.

3. Review and compilation, A review oriented toward the relative value of objectives should take precedence over a review of methods for achieving objectives. Technical review ensures that the figures and estimates of requirements are accurate and consistent with prior direction and assumptions regarding input costs, historic spending, and spending envelopes.

Sedangkan pada fase kedua yaitu Legislative Review and Approval, dimana pembahasan dan persetujuan yang dilakukan oleh legislatif yang dikemukakan oleh Mullins dalam Shah(ed) (2007) terdapat beberapa kriteria yang mesti dipenuhi, budget coverage, review, dan scope of approval, atau lebih lengkap penjelasan dalam fase kedua dalam perencanaan anggaran ini adalah sebagai berikut:

1. Budget coverage; A critical element in the legislative review and approval stage is the quality of budgetary information. Informed review is information intensive. If budget deliberations are to meaningfully reflect the municipal government's priorities and policies, complete information must be provided.

2. Review; The council must have authority to collect information and request testimony of administrative officials on the merits of all elements of the proposed budget. The council needs an independent means of information analysis.

3. Scope of approval; Legislative authority must be meaningful.Council deliberations should include consideration of aggregate revenues and expenditures, as well as spending at the programmatic and organizational unit levels. The legislature should have the authority to amend budgetary submissions.

Dalam penganggaran, tidak dinafikkan terdapat nilai-nilai lain yang juga memberikan andil dalam pengambilan keputusan yang dibuat. Wildavsky (1966) misalnya, mengemukakan bahwa "political rationality is the fundamental kind of reason, because it deals with the preservation and improvement of decision structures, and decision structure are the source of all decision....the program budget is suffused with policy politics". Senada dengan pendapat Wildavsky tersebut, Lee, Jr., Johnson dan Joyce (2013) berpendapat terdapat nilai politik dan fragmentasi dalam siklus anggaran pada fase awal penganggaran, sehingga setiap organisasi yang mengajukan anggaran hanya fokus pada kepentingannya sendiri dan menafikan perspektif di luar mereka, sebagaimana yang diungkapkan bahwa "each organizational unit is concerned with its own survival and advancement. Line agencies and their subunit attempt to protect against budget cut and may strive for increased resources". Menurut ahli ini tentang fragmentasi, "organizational units within line agencies tend to be concerned primarily with their own programs and frequently fail to take a broad perspective (Lee, Jr., Johnson dan Joyce, 2013)". 
Secara tradisional, Bastian (2010) mengatakan bahwa prinsip penganggaran yang sangat terkenal adalah the Three Es yaitu ekonomis, efisien, dan efektif. Ekonomis hanya berkaitan dengan input; efektivitas hanya berkaitan dengan output; sedangkan efisiensi adalah kaitan antara input dan output. Hal ini senada dengan hujah Rosenbloom dan Kravchuck (2005) bahwa "........budgeting promotes the values of efficiency, economy, and managerial effectiviness", yang dalam perkembanganya prinsip-prinsip anggaran menjadi sangat dinamis. Munculnya konsep good governance sangat menekankan prinsip yang salah satunya adalah akuntabel sebagai tujuan penganggaran. Hal ini diperkuat oleh Wildavsky (1978) bahwa "control over public money and accountability to public authority were among the earliest purposes of budgeting." Dalam konteks inilah anggaran pelaksanaan Pemilihan Walikota Solok menjadi tidak tidak efisien, sehingga anggaran menjadi tidak akuntabel karena dipengaruhi oleh nilai-nilai politik dan fragmentasi oleh aktor yang terlibat dalam proses penganggarannya. Untuk itu kerangka teori yang penulis gunakan dalam tulisan ini mengacu pada pendapat Mullins dalam Shah(ed) (2007) yang telah penulis uraikan sebelumnya, terutama fase pertama dalam budget cycle tersebut, yaitu; policy guidance and outlook, instruction and expenditure standard, dan review and compilation, dan fase kedua yaitu Legislative Review and Approval, yang didalamnya terdapat beberapa kriteria yang mesti dipenuhi, yaitu; budget coverage, review, dan scope of approval untuk menjawab permasalahan terjadinya ketidakefisienan yang berujung pada tidak akuntabelnya anggaran Pemilihan Walikota Solok pada Pilkada serentak Tahun 2015.

\section{HASIL DAN PEMBAHASAN}

\section{Tahapan Budget Preparation and Formulation (Persiapan dan Formulasi Anggaran) pada Penganggaran Pelaksanaan Pemilihan Walikota Solok}

Persiapan penyelanggaraan Pemilihan Gubernur, Bupati dan Walikota Tahun 2015 mengalami proses panjang. Termasuk juga dalam menyiapkan pelbagai kebijakan yang terkait dengan proses penyelenggaraan Pilkada tersebut termasuk kebijakan tentang anggaran Pilkada. Banyak sekali kebijakan yang telah dikeluarkan terkait dengan Pilkada maupun anggaran Pilkada, termasuk juga tarik ulur perubahan substansi Pilkada langsung menjadi tidak langsung dengan dalih dampak negatif Pilkada langsung terhadap tata kelola pemerintahan daerah dan mahalnya biaya politik pencalonan dalam Pilkada langsung. Sehingga sampai pada tahun pelaksanaan Pilkada serentak secara nasional untuk pertama kalinya akan digelar pada Tahun 2015 itu, barulah kebijakan pelaksanaan Pilkada secara langsung tersebut menjadi keputusan final dengan mengembalikan pemilihan kepada rakyat secara langsung baru dapat ditetapkan oleh pemerintah ketika itu. Pilkada langsung di Indonesia yang saat ini terjadi adalah sebagai konsekuensi logis atas ditetapkannya UU Nomor 32 Tahun 2004 tentang Pemerintah Daerah yang didalamnya pertama kali mengatur tentang pemimpin daerah yang bisa langsung dipilih oleh rakyat. Dalam perkembangannya UU tentang Pemerintah Daerah ini mengatur masing-masing persoalan tentang urusan pemerintah daerah yang dipisahkan dengan urusan Pilkada dan Desa. Kemudian lahirlah kebijakan terpisah terkait Pemerintah Daerah ini dengan diawali dengan aturan tentang Pilkada dengan disahkannya Undang-Undang Pemilihan Gubernur, Bupati dan Walikota Nomor 22 Tahun 2014 pada Tanggal 30 September 2014.

UU ini merupakan arus balik atas proses demokrasi yang terjadi, karena kepala daerah kembali dipilih oleh perwakilan rakyat di DPRD. Tekanan politik yang kuat terhadap proses perubahan pemilihan kepala daerah ini sehingga menyebabkan pemerintah saat itu, mengeluarkan Penetapan Peraturan Pemerintah Pengganti Undang-Undang (Perppu) Nomor 
1 Tahun 2014 tentang Pemilihan Gubernur, Bupati dan Walikota. Perppu ini menegaskan untuk mengembalikan pelaksanaan Pilkada secara langsung dan membatalkan UU Nomor 22 Tahun 2014. Dan, tak lama kemudian DPR menetapkan Undang-Undang (UU) Nomor 1 Tahun 2015 tentang Perppu Nomor 1 Tahun 2014 tentang Pemilihan Gubernur, Bupati, dan Walikota menjadi Undang-Undang. Pengesahan Perppu ini menjadi UU yang merupakan penegasan untuk mengembalikan hak rakyat bahwa kepala daerah mesti dipilih kembali secara langsung oleh rakyat. Revisi atas UU Nomor 1 Tahun 2015 kembali dilakukan pemerintah yang kemudian mengesahkan UU Nomor 8 Tahun 2015 tentang Perubahan atas UU Nomor 1 Tahun 2015 tentang Penetapan Perppu Nomor 1 Tahun 2014 tentang Pemilihan Gubernur, Bupati, dan Walikota menjadi Undang-Undang. Kebijakan tersebut dirancang agar pelaksanaan Pilkada lebih efektif, efisien, lebih murah, dan mudah ditangani ketika terjadi permasalahan (KPU Kota Solok, 2016:1)

Berakhirnya turbulensi soal kebijakan Pilkada tersebut, pada Tahun 2015 itu juga dicanangkan sebagai Pilkada Serentak Nasional Gelombang I (Pertama) dari 7 (Tujuh) gelombang sesuai amanat UU Nomor 8 Tahun 2015 yang berlangsung Pada 9 Desember 2015 silam. Pemungutan suara serentak secara nasional sesuai Pasal 201 UU Nomor 8 Tahun 2015 dilakukan bagi Gubernur dan Wakil Gubernur, Bupati dan Wakil Bupati, serta Walikota dan Wakil Walikota yang masa jabatannya berakhir pada Tahun 2015 dan Bulan Januari sampai dengan Bulan Juni Tahun 2016 yang dilaksanakan pada tanggal dan bulan yang sama pada Bulan Desember 2015. Kesiapan pemerintah dalam mengeluarkan kebijakan terkait Pilkada serentak tersebut tentu sangat diperlukan sebagai dasar dilaksanakannya pesta demokrasi di daerah. Pada Gelombang I (Pertama) pelaksanaan Pilkada serentak nasional ini sebanyak 269 daerah yang turut serta melaksanakannya, termasuk Pemilihan Gubernur dan Wakil Gubernur Provinsi Sumatera Barat dan Pemilihan Bupati/Walikota dan Wakil Bupati/Wakil Walikota yang dilaksanakan di 13 (tiga belas) kabupaten/kota yang melakukan di Provinsi Sumatera Barat. Dan, Pilkada Kota Solok termasuk yang melaksanakan Pilkada serentak secara nasional yang juga bersamaan dengan pelaksanaan Pemilihan Gubernur dan Wakil Gubernur Provinsi Sumatera Barat. Akhir Masa Jabatan (AMJ) Walikota dan Wakil Walikota Solok berakhir pada Tanggal 31 Agustus 2015. Sehingga berdasarkan Pasal 201 UU Nomor 8 Tahun 2015, suksesi kepemimpinan di Kota Solok tersebut harus dilakukan serentak dengan Pemilihan Gubernur dan Wakil Gubernur Sumatera Barat yang akan dilakukan pada Tanggal 9 Desember 2015 yang termasuk Pilkada serentak nasional Gelombang Pertama.

Dalam rangka mengantisipasi perubahan kebijakan tentang pelaksanaan Pilkada tersebut, tentunya mempunyai konsekuensi logis terhadap kebijakan terkait anggaran pelaksanaan Pilkada. Sebagaimana yang dikemukan oleh Mullins (2007) bahwa pedoman kebijakan yang diberikan melalui proses dari pusat ke daerah berupa harapan dan parameter tertentu, dimana harapan dan parameter tersebut mesti dilakukan oleh pelaksana kebijakan nantinya yang mesti mempertimbangkan kemampuan fiskal daerah, sumber daya yang dimiliki, perkiraan biaya yang diperlukan, dan asumsi, serta plafon atau pagu anggaran yang dimiliki dan prioritas kebijakan. Untuk itu, pemerintah telah mengeluarkan beberapa kebijakan yang terkait dengan anggaran Pilkada dimana pada proses perencanaan anggaran Pilkada Kota Solok berpedoman kepada Permendagri Nomor 51 Tahun 2015 yang merupakan perubahan atas Permendagri Nomor 44 Tahun 2015 tentang Pengelolaan Dana Kegiatan Pemilihan Gubernur dan Wakil Gubernur, Bupati dan Wakil Bupati, serta Walikota dan Wakil Walikota. Permendagri Nomor 44 Tahun 2015 ini merupakan pengganti dari Permendagri Nomor 44 Tahun 2007 tentang Pedoman Pengelolaan Belanja Pemilihan Umum Kepala Daerah dan Wakil Kepala Daerah sebagaimana yang telah diubah dengan Permendagri 
Nomor 57 Tahun 2009 tentang Perubahan atas Permendagri Nomor 44 Tahun 2007. Revisi atas Permendagri No 44 Tahun 2015 menjadi Permendagri Nomor 51 Tahun 2015 dilakukan dengan mengubah lampirannya yaitu perubahan pada format standar penghitungan kebutuhan anggaran untuk kegiatan pemilihan. Penganggaran Pilkada serentak yang melibatkan beberapa aktor penting di daerah ini yaitu KPUD Kota Solok, Pemerintah Kota Solok dalam hal ini adalah TAPD, dan DPRD Kota Solok telah melahirkan kebutuhan anggaran pelaksanaan Pemilihan Walikota dan Wakil Walikota Solok pada Tahun 2015 yang dapat ditabulasikan berdasarkan NPHD yang dibuat antara KPU Kota Solok dengan Pemerintah Kota Solok sebagai berikut:

Tabel 1.

Rekapitulasi Kebutuhan Anggaran Pilkada Kota Solok Tahun 2015

\begin{tabular}{|c|l|r|lc|}
\hline No & \multicolumn{1}{|c|}{ NPHD } & Tanggal & \multicolumn{2}{c|}{ Jumlah } \\
\hline 1 & NPHD Tahap I & 16 November 2015 & Rp. & 4.813 .047 .500 \\
\hline 2 & NPHD Tahap II & 22 Januari 2016 & Rp. & 587.963 .000 \\
\hline \multicolumn{2}{|r|}{ Total Anggaran Pilkada Kota Solok } & Rp. & 5.401 .010 .500 \\
\hline
\end{tabular}

Sumber: Diolah dari Anggaran Pilkada Kota Solok Tahun 2015

Penetapan hibah untuk Pilkada mesti dianggarkan dalam APBD yang proses penganggarannya mesti dilakukan sebelum tahun Pilkada dilaksanakan. Dalam hal ini, Kota Solok telah melakukan hal tersebut karena anggaran Pilkada Kota Solok telah masuk dalam dokumen perencanaan dan anggaran (policy anticipation) Kota Solok Tahun 2015 walaupun masih terjadi adendum terhadap dokumen anggaran tersebut. Hal lain, Pilkada yang dibiayai oleh APBD ini telah menjadi beban juga bagi daerah karena dapat mengganggu belanja untuk kepentingan publik yang mesti dialihkan untuk menanggung biaya Pilkada, walaupun tidak sampai mengganggu belanja Bidang Pendidikan dan Kesehatan seperti yang terjadi pada Pilkada 2010 di Kota Solok yang lalu. Hasil penelusuran penulis terhadap APBD Kota Solok Tahun Anggaran 2015 total jumlah APBD hampir 1 (satu) Trilyun Rupiah atau tepatnya sebesar Rp. 998.814.374.183, dengan PAD hanya sebesar Rp. 28.259.393.577. Jika penulis bandingkan dengan data APBD Kota Solok besaran belanja anggaran di beberapa belanja publik memang tidak terdapat penurunan jumlah belanja seperti di bidang pendidikan, kesehatan, atau belanja lainnya atau sampai mengurangi belanja publik untuk membiayai kegiatan pemilihan walikota dan wakil walikota, malah di beberapa jenis belanja publik mengalami peningkatan dari tahun anggaran sebelumnya. Belanja Hibah Pilkada Kota Solok untuk Tahun 2015 tidak berasal dari pengalihan belanja publik untuk membiayai kegiatan pemilihan Walikota dan Wakil Walikota, akan tetapi jika tidak ada belanja Hibah Pilkada tentu kenaikan belanja yang lainnya tentu kenaikannya akan lebih banyak. Dan, berdasarkan APBD Kota Solok untuk Tahun Anggaran 2015 alokasi belanja hibah meningkat menjadi Rp. 8.415.155.000 atau naik sebesar 18,25\% dibandingkan tahun anggaran sebelumnya yang semestinya bisa jadi hibah ini bisa diperuntukkan untuk belanja publik lainnya selain belanja hibah Pilkada. Artinya, anggaran Pilkada walaupun dialokasikan kedalam dana hibah tetap menjadi beban bagi pemerintah daerah ketika bersumber dari APBD. 
Instruksi dan standar belanja Pilkada dalam tataran implementasi yang mengalami beberapa kali perubahan. Pendanaan Pilkada berdasarkan UU Nomor 1 Tahun 2015 dibebankan pada Anggaran Pendapatan dan Belanja Negara dan dapat didukung melalui Anggaran Pendapatan dan Belanja Daerah sesuai dengan ketentuan peraturan perundangundangan. Artinya bahwa, dalam aturan yang ada pada saat itu beban pendanaan Pilkada utamanya bersumber dari APBN. Tapi, dalam praktiknya tetap saja yang menjadi sumber pendanaan utama adalah berasal dari APBD termasuk dalam Pemilihan Walikota dan Wakil Walikota Solok. Dan, apa yang terjadi di Kota Solok dengan memasukkan anggaran Pilkada ke dalam APBD Kota Solok berdasarkan UU Nomor 1 Tahun 2015 ini merupakan bersifat dana pendukung karena pendanaan penyelenggaraan Pemilihan Gubernur, Bupati, dan Walikota yang menjadi beban APBN. Tapi,jika melihat Perppu Nomor 1 Tahun 2014 didalam ketentuan peralihan Pasal 200 menyebutkan bahwa pendanaan kegiatan Pemilihan Gubernur, Bupati, dan Walikota yang dilaksanakan pada Tahun 2015 dibebankan pada Anggaran Pendapatan dan Belanja Daerah. Jadi, terdapat perbedaan yang cukup signifikan terhadap sumber pembiayaan utama dalam penyelenggaraan Pilkada ini dalam Perppu Nomor 1 Tahun 2014 tersebut dimana lebih dititikberatkan pada APBD. Padahal, pembiayaan Pilkada yang dibebankan kepada APBN akan memastikan keserentakan penyelenggaran dan standar anggaran di tiap daerah sehingga penyelenggaraan Pilkada akan menjadi lebih efektif dari sisi penyelenggaraan, dan efisien, serta ekonomis dari sisi anggaran seperti yang diinginkan dalam UU Nomor 1 Tahun 2015 tersebut.

Hal inilah yang menjadi dasar keluarnya Surat Edaran Menteri Dalam Negeri (SE Mendagri) untuk memberikan kepastian instruksi dan mengatur Pilkada serentak secara nasional tersebut diantara jeda waktu ditetapkannya UU Nomor 1 Tahun 2015 tertanggal 2 Februari 2015 dengan keluarnya amandemen UU Nomor 1 Tahun 2015 menjadi UU Nomor 8 Tahun 2015 tentang pemilihan Gubernur, Bupati dan Walikota pada Tanggal 18 Maret 2015. Menteri Dalam Negeri Republik Indonesia mengeluarkan Surat Edaran Nomor 900/1196/SJ Tanggal 9 Maret 2015 tentang Pendanaan Penyelenggaraan Pemilihan Gubernur, Bupati dan Walikota 2015. Dalam SE Mendagri tersebut terdapat instruksi yang menyangkut pendanaan Pilkada. SE Mendagri ini juga terdapat pertentangan terutama pada poin pertama bahwa pendanaan Pilkada dibebankan kepada APBD padahal ketika itu dalam UU Pilkada yang berlaku masih membebankan anggaran Pilkada kepada APBN. Amanat SE Mendagri ini kembali memberlakukan Pilkada serentak dengan pendanaan bersama oleh Provinsi dengan Kabupaten/Kota yang akan menyelenggarakan Pilkada. Dalam prakteknya, Pilkada serentak ini juga telah dilakukan oleh Kota Solok dengan Provinsi Sumatera Barat sebelumnya yaitu pada Pilkada Tahun 2010 yang lalu. Tentunya, pilkada serentak tersebut adalah untuk menciptakan penyelenggaraan pemilu yang efisien dan efektif untuk meminimalisir membengkaknya biaya penyelenggaraan Pilkada yang salah satu penyebabnya adalah terdapatnya beban biaya honor penyelenggara pada waktu yang berbeda untuk kedua kalinya. Hal ini tentu akan terjadi jika Pilkada dibuat tidak serentak sehingga honor penyelenggara harus dibayarkan dalam dua Pilkada yang berbeda. Dan di sisi yang lain, efisiensi, efektivitas dan proporsionalitas dalam UU Nomor 1 Tahun 2015 tersebut agaknya sulit untuk dicapai mengingat pelaksanaan kampanye difasilitasi oleh KPU sebagai penyelenggara Pilkada. Disamping itu, dalam Permendagri Nomor 51 Tahun 2015 pelaksanaan kegiatan kampanye juga dianggarkan melalui anggaran Pilkada seperti: debat publik, bahan kampanye, alat peraga, dan iklan media massa cetak dan media massa elektronik. Sebagaimana yang dikemukan oleh Mullins (2007) bahwa dalam aturan penganggaran harus mempertimbangkan lingkungan fiskal yang salah satunya adalah upaya untuk mereduksi pembengkakkan 
anggaran. Untuk lebih jelasnya besaran anggaran yang dialokasikan untuk pelaksanaan kegiatan kampanye adalah sebesar 19,8\% dari total anggaran Pilkada yang dibutuhkan oleh Kota Solok dalam Pemilihan Walikota dan Wakil Walikota, yang dapat dilihat rinciannya sebagai berikut:

Tabel 2.

Anggaran Pelaksanaan Kampanye Pilkada Kota Solok Tahun 2015

\begin{tabular}{|l|l|lr|}
\hline No & Uraian Kegiatan & Jumlah & \\
\hline 1 & Debat publik/debat terbuka antar pasangan calon & Rp. & 67.925 .000 \\
\hline 2 & Bahan kampanye & Rp. & 597.600 .000 \\
\hline 3 & Alat peraga & Rp. & 60.000 .000 \\
\hline 4 & Iklan media massa cetak dan media massa elektronik & Rp. & 526.800 .000 \\
\hline Jumlah Total & Rp. & 252.325 .000 \\
\hline
\end{tabular}

Diolah dari Dokumen Perencanaan Anggaran Kota Solok 2015.

Pada Pilkada serentak 2015 di Kota Solok ini, sudah terdapat pendanaan bersama yang dilakukan antara Pemilihan Walikota Kota dan Wakil Walikota Solok dengan Pemilihan Gubernur dan Wakil Gubernur Sumatera Barat, dengan menanggung beberapa kebutuhan belanja barang untuk penyelenggaraan Pilkada oleh KPU Provinsi. Tetapi hal tersebut bukanlah merupakan kesepakatan antara Gubernur Sumatera Barat dengan Bupati/Walikota di Sumatera Barat yang akan melaksanakan helat Pilkada serentak yang sesuai dengan amanat Permendagri Nomor 44 Tahun 2015. Tapi, merupakan hasil rapat koordinasi KPU Provinsi dengan 13 (Tiga Belas) KPU Kabupaten/Kota yang melaksanakan Pilkada serentak ketika itu. Berdasarkan penelusuran atas dokumen anggaran Pilkada Serentak yang dilakukan di Kota Solok didapatkan informasi mengenai besaran anggaran yang dibantu oleh KPU Provinsi Sumatera Barat yang penulis dapatkan, sebagai berikut:

Tabel 3.

Daftar Belanja Pilkada yang ditanggung oleh Pilgub Sumatera Barat

\begin{tabular}{|c|l|c|c|r|}
\hline No & \multicolumn{1}{|c|}{ Uraian } & Volume & Harga & \multicolumn{1}{c|}{ Jumlah } \\
\hline 1 & Tinta & 121 & 25000 & 3.025 .000 \\
\hline 2 & Formulir C & & & 17.315 .000 \\
\hline 3 & Formulir D & 121 & 10000 & 938.000 \\
\hline 4 & Karet & 123 & 4000 & 1.210 .000 \\
\hline 5 & Lem Perekat & 255 & 1000 & 492.000 \\
\hline 6 & Kantong plastik besar & 621 & 2000 & 255.000 \\
\hline 7 & Ballpoint & 383 & 2500 & 1.242 .000 \\
\hline 8 & Spidol Kecil & 125 & 8500 & 957.000 \\
\hline 9 & Spidol Besar & 123 & 12500 & 1.062 .500 \\
\hline 10 & Gembok & Jumlah & 1.537 .500 \\
\hline \multicolumn{3}{|l|}{} \\
\hline
\end{tabular}

Sumber : Diolah dari Dokumen Perencanaan Anggaran Kota Solok 2015. 
Tabel di atas jumlah anggaran yang ditanggung oleh Provinsi Sumatera Barat melalui KPU Provinsi Sumatera Barat adalah sejumlah Rp. 28.034 .000 atau hanya sebesar 1\% dari anggaran yang dianggarkan pada Pilkada serentak pada Tahun 2015 yang dibantu pembiayaannya melalui Pemilihan Gubernur dan Wakil Gubernur (Pilgub) Provinsi Sumatera Barat. Beban terbesar masih terdapat pada anggaran KPU Kota Solok yang disamping membiayai pelaksanaan Pemilihan Walikota dan Wakil Walikota (Pilwako) Kota Solok juga mesti menanggung beban pada anggaran mereka dengan adanya pelaksanaan Pilgub Provinsi Sumatera Barat. Semangat efisiensi, efektivitas, dan proporsionalitas anggaran dalam Pilkada serentak nasional dimana pendanaan mestinya menjadi tanggungan bersama belum dilakukan sesuai dengan beban kerja, sehingga dapat dikatakan bahwa Pemilu serentak yang terjadi saat ini masih dalam tataran pelaksanaannya saja. Tapi, tidak dapat dipungkiri juga bahwa dalam Pilkada serentak nasional Tahun 2015 di Sumatera Barat sudah terdapat pendanaan bersama (cost sharing) seperti yang diamanatkan oleh kebijakan Pilkada serentak nasional, terutama yang terjadi di Kota Solok walaupun belum proporsional. Menurut Mullins (2007) instruksi dan standar belanja tidak perlu dirinci sedemikian rupa karena penyusunan anggaran memerlukan fleksibilitas dalam menetapkan rencana pengeluaran untuk mengerahkan seluruh sumber daya yang dimiliki secara efektif mungkin dalam mengejar tujuan program, termasuk upaya untuk melakukan cost sharing ini yang memungkinkan terjadinya fleksibilitas sumber anggaran.

Penyelenggaraan Pilkada serentak Gelombang Pertama di Indonesia terdapat beberapa catatan penting, perubahan pelbagai regulasi terutama beban anggaran Pilkada yang bergeser dari APBN menjadi APBD mengganggu efektivitas penganggaran Pilkada karena belum didapatkan kepastian alokasi anggaran dari Pemerintah Daerah. Beban anggaran Pilkada yang terletak pada APBD dikhawatirkan akan membuka ruang terciptanya konflik kepentingan bagi kepala daerah yang berasal dari petahana. Tapi yang terjadi di Kota Solok, pergeseran regulasi tersebut tidak mengganggu efektivitas penganggaran Pilkada yang dibebankan kepada APBD, dan petahana tidak terlalu punya banyak kepentingan terhadap proses penganggaran Pilkada yang diajukan oleh KPU Kota Solok, padahal petahana baik Walikota Solok maupun Wakil Walikota Solok yang menjabat ketika itu, keduanya masingmasing maju dalam pencalonan Wali Kota Solok dengan pasangan berbeda untuk Periode 2016-2021 ketika itu. Hal tersebut sebagaimana yang dikemukakan oleh Mullins (2007) bahwa pada proses penganggaran ketika akan diputuskan kebutuhan besaran anggaran tersebut tetap saja yang menjadi pertimbangan adalah prioritas, plafon anggaran, jadual pelaksanaan anggaran, instruksi (pedoman kebijakan), proses pembahasan internal, finalisasi pembahasan dan pengajuan anggaran. Secara prinsip di dalam kebijakan Kebijakan Umum Anggaran (KUA) dan Prioritas Plafon Anggaran Sementara (PPAS) Kota Solok telah disebutkan bahwa pemerintah daerah akan mengalokasikan anggaran untuk Hibah untuk penyelenggaraan Pilkada kepada KPU Kota Solok sehingga kepastian anggaran untuk melaksanakan kegiatan tersebut sudah terdapat jaminan pelaksanaannya dari sisi anggaran.

Proses penyusunan anggaran Pilkada Kota Solok, KPU secara internal terlebih dahulu membuat rencana anggaran kebutuhan penyelenggaraan Pilkada. Sebagaimana yang diungkapkan oleh Mullins (2007) bahwa segala jenis kesalahan dalam perencanaan anggaran mesti dilakukan koreksi, kajian teknis memastikan bahwa angka-angka dan perkiraan kebutuhan yang akurat dan konsisten dengan arah sebelumnya, anggaran sebelumnya, asumsi mengenai biaya masukan, standar biaya lainnya, dan pagu anggaran. Jenis kegiatan mesti sesuai dengan plafon atau pagu anggaran yang tersedia. Kajian teknis memastikan bahwa angka-angka dan perkiraan kebutuhan yang akurat dan konsisten dengan dokumen 
perencanaan yang telah ditetapkan sebelumnya dan asumsi mengenai jenis belanja, satuan harga, dan pagu belanja, serta plafon anggaran yang tersedia. Hal tersebut juga diatur melalui Permendagri Nomor 44 tahun 2015 tentang Pengelolaan Dana Kegiatan Pemilihan Gubernur dan Wakil Gubernur, Bupati dan Wakil Bupati, serta Walikota dan Wakil Walikota dalam Pasal 7 ayat 2 bahwa kebutuhan pendanaan kegiatan pemilihan Bupati dan Wakil Bupati/Walikota dan Wakil Walikota diusulkan oleh KPU Kabupaten/Kota dan Panwas Kabupaten/Kota kepada Bupati/Walikota. Inilah yang menjadi dasar KPU Kota Solok dalam menyusun rencana kebutuhan biaya pemilihan Walikota dan Wakil Walikota Solok 2015 yang akan disampaikan kepada Walikota Solok untuk ditampung ke dalam Rencana Satuan Kerja Anggaran (RKA) Satuan Kerja Pengelola Keuangan Daerah. Dan, divisi yang terdapat dalam Struktur Organisasi KPU Kota Solok yang bertugas untuk menyusun rancangan dokumen anggaran kebutuhan Pilkada ini adalah Divisi Keuangan, Logistik, Umum dan Badan Urusan Rumah Tangga yang harus mengakomodir seluruh kebutuhan dalam pelaksanaan Pilkada ini.

\section{Tahapan Legislative Review and Approval (Pembahasan dan Persetujuan Oleh Lembaga Legislatif) Pada Penganggaran Pelaksanaan Pemilihan Walikota Solok}

Laporan penyelenggaraan Pemilihan Walikota dan Wakil Walikota Kota Solok Tahun 2015 disebutkan juga bahwa setelah dilakukan pembahasan tentang Rencana Kerja Anggaran KPU Kota Solok dengan Tim TAPD Kota Solok, proposal anggaran pelaksanaan Pilkada Kota Solok kemudian disampaikan kepada Badan Anggaran DPRD Kota Solok untuk dibahas dan dimintai persetujuan. Setelah dibahas dan disetujui oleh DPRD Kota Solok selanjutnya disusun menjadi Dokumen Pelaksanaan Anggaran Pemilihan Walikota Solok dan Wakil Walikota Solok Tahun 2015. Hal yang mendasari legislatif dalam membahas dan melakukan persetujuan terhadap anggaran yang diajukan oleh KPU Kota Solok melalui TAPD Kota Solok, adalah aturan hukum atau regulasi dan kemampuan keuangan daerah menjadi hal yang utama, disamping terdapatnya informasi yang jelas tentang proses pengajuan Pilkada atau prosedur yang sesuai dengan aturan yang berlaku. Hal ini, seperti yang diungkapkan oleh Mullins (2007) bahwa tahapan kritis dalam pembahasan yang dilakukan oleh legislatif dan persetujuan terhadap pengajuan proposal anggaran yang dilakukan adalah kualitas dari informasi penganggaran proposal berkenaan. Lalu, hasil persetujuan anggaran hibah tersebutlah yang dituangkan menjadi Naskah Perjanjian Hibah Daerah (NPHD). Dari hasil identifikasi penulis berdasarkan Dokumen Pelaksanaan Anggaran Pemilihan Walikota dan Wakil Walikota Solok Tahun 2015 adalah sebesar Rp. 5.401.010.500 dengan rincian berdasarkan tahun anggaran adalah sebesar Rp. 4.813.047.500 pada Tahun Anggaran 2015 dan sebesar Rp. 587.963.000 pada Tahun Anggaran 2016, didapatkan data sebagai berikut:

Tabel 4.

Rekapitulasi Dokumen Pelaksanaan Anggaran Pemilihan Walikota dan Wakil Walikota Solok Tahun 2015

\begin{tabular}{|l|c|c|c|c|}
\hline \multirow{2}{*}{ No. } & \multirow{2}{*}{ Uraian } & \multirow{2}{*}{$\begin{array}{c}\text { Total } \\
\text { Anggaran }\end{array}$} & \multicolumn{2}{c|}{ Pembagian Anggaran } \\
\cline { 5 - 5 } & & APBD 2015 & APBD 2016 \\
\hline I & Honorarium dan Uang Lembur & 1.492 .230 .000 & 1.282 .240 .000 & 209.990 .000 \\
\hline II & $\begin{array}{l}\text { Pembelian dan Pengadaan Barang } \\
\text { dan Jasa }\end{array}$ & 3.908 .780 .500 & 3.530 .807 .500 & 377.973 .000 \\
\hline \multicolumn{2}{|c|}{ Jumlah Total } & & & $\mathbf{5 . 4 0 1 . 0 1 0 . 5 0 0}$ \\
\hline
\end{tabular}

Sumber: Diolah dari NPHD Pemerintah Kota Solok dengan KPU Kota Solok. 
Ketika anggaran Pemilihan Walikota dan Wakil Walikota Solok Tahun 2015 ini diajukan, dasar pembuatan anggaran Pemilihan Walikota dan Wakil Walikota Solok Tahun 2015 waktu itu masih menggunakan Permendagri Nomor 57 Tahun 2009 tentang Perubahan atas Peraturan Menteri Dalam Negeri Nomor 44 Tahun 2007 tentang Pedoman Pengelolaan Belanja Pemilihan Umum Kepala Daerah dan Wakil Kepala Daerah ketika itu. Anggaran pelaksanaan Pemilihan Walikota dan Wakil Walikota Solok Tahun 2015 bersumber dari APBD maka anggaran tersebut juga mengacu kepada Permendagri yang mengatur tentang penyusunan APBD untuk Tahun Anggaran 2015 sebagaimana yang diatur melalui Permendagri Nomor 32 Tahun 2014 tentang Pedoman Penyusunan Anggaran Pendapatan dan Belanja Daerah Tahun Anggaran 2015. Dalam Permendagri Nomor 32 Tahun 2014 tersebut penganggaran belanja hibah yang bersumber dari APBD berpedoman kepada peraturan kepala daerah yang telah disesuaikan dengan Permendagri Nomor 32 Tahun 2011 tentang Pedoman Pemberian Hibah dan Bantuan Sosial yang Bersumber dari APBD. Sehingga, terdapatnya perbedaan pemahaman terhadap regulasi yang berlaku merupakan hal yang wajar terjadi karena banyak sekali regulasi yang terkait dengan proses penganggaran Pilkada serentak ini.

DPRD mempunyai fungsi anggaran yaitu dalam membahas dan menyetujui rancangan anggaran pendapatan dan belanja daerah bersama kepala daerah. Sehingga dalam hal ini, anggaran Pemilihan Walikota dan Wakil Walikota Solok Tahun 2015 yang bersumber dari APBD tersebut merupakan tugas dan wewenang DPRD untuk membahas dan menyetujui rancangan anggaran yang dibuat oleh KPU Kota Solok. Disamping itu, DPRD juga mempunyai alat kelengkapan yang khusus membidangi persoalan anggaran yang didalamnya tentu saja juga membidangi persoalan anggaran Pemilihan Walikota dan Wakil Walikota Solok Tahun 2015 yaitu Badan Anggaran DPRD Kota Solok. Badan inilah yang melakukan pembahasan sampai dengan memberikan rekomendasi persetujuan kepada pimpinan DPRD terhadap usulan anggaran belanja hibah Pemilihan Walikota dan Wakil Walikota Solok Tahun 2015 yang dilakukan oleh KPU Kota Solok. Hal ini sama dengan yang diungkapkan oleh Mullins (2007) bahwa legislatif mempunyai kewenangan untuk mengumpulkan informasi dan meminta kesaksian dari pejabat yang berwenang dalam pengajuan anggaran terhadap manfaat dari setiap anggaran dan biaya yang diajukan.

Mullins (2007) juga berpendapat bahwa proses pembahasan seharusnya dilakukan secara terbuka termasuk juga harus menerima masukan baik dari pengusul maupun dari perspektif independen maupun penilaian dari legislatif itu sendiri terhadap pengajuan anggaran yang dilakukan. Keterlibatan masyarakat dalam proses pembahasan anggaran Pemilihan Walikota dan Wakil Walikota Solok Tahun 2015 secara langsung pada forum pertemuan antara KPU dan DPRD Kota Solok memang tidak ada, seperti pemberian masukan yang mesti dilakukan oleh masyarakat dalam public comment atas anggaran yang diajukan sebagaimana yang dikemukakan oleh Mullins (2007) bahwa proses pembahasan harus terbuka dan menerima masukan dari masyarakat sipil atau komen dari publik tentang usulan anggaran yang dibahas, hal ini tidak terjadi dalam proses penganggaran Pilkada serentak di Kota Solok. Selain celah aturan untuk hal tersebut tidak diatur, hal ini juga bukan merupakan mekanisme yang ada dalam Permendagri tentang anggaran Pemilihan Kepala Daerah yang mengatur mesti terdapat keterlibatan masyakarat secara langsung dalam pembahasan anggaran yang dilakukan.

Kewenangan DPRD dalam membahas dan memberikan persetujuan terhadap Anggaran Pemilihan Walikota dan Wakil Walikota Solok telah berdasarkan pada aturan yang berlaku. Pembahasan terhadap pengajuan anggaran tersebut berada pada Badan Anggaran 
DPRD Kota Solok sampai dengan proses persetujuan yang diambil. Peraturan yang mendasari kewenangan DPRD tersebut diantaranya adalah mengacu kepada Undang-Undang Nomor 27 Tahun 2009 tentang Majelis Permusyawaratan Rakyat, Dewan Perwakilan Rakyat, Dewan Perwakilan Rakyat Daerah, dan Dewan Perwakilan Rakyat Daerah; dan Peraturan Pemerintah Nomor 16 Tahun 2010 tentang Pedoman Penyusunan Peraturan Dewan Perwakilan Rakyat Daerah; serta Keputusan DPRD Kota Solok Nomor 1 Tahun 2014 tentang Tata Tertib Dewan Perwakilan Rakyat Daerah Kota Solok. Berdasarkan beberapa regulasi tersebutlah DPRD melaksanakan kewenangan yang dimilikinya, sebagaimana yang diungkapkan oleh Mullins (2007) bahwa kekuasaan legislatif sangatlah berarti, dan sudah seharusnyalah legislatif mempunyai kekuasaan untuk melakukan merubah anggaran yang diajukan kepadanya.

Dalam mengambil keputusan dalam persetujuan terhadap perencanaan anggaran Pemilihan Walikota dan Wakil Walikota Solok Tahun 2015 melalui Rapat Badan Anggaran yang juga diatur dalam Tata Tertib Dewan Perwakilan Rakyat Daerah Kota Solok Nomor 1 Tahun 2014 tersebut bahwa Rapat Badan Anggaran merupakan rapat Badan Anggaran yang dipimpin oleh Ketua dan Wakil Ketua Badan Anggaran. Rapat Badan Anggaran menurut Tata Tertib Dewan Perwakilan Rakyat Daerah Kota Solok Nomor 1 Tahun 2014 tersebut merupakan rapat tertutup. Setelah terdapat persetujuan pada Badan Anggaran DPRD Kota Solok pembahasan Anggaran Pemilihan Walikota dan Wakil Walikota Solok selanjutnya dilakukan oleh Komisi di DPRD dalam hal ini Komisi III DPRD. Komisi III DPRD Kota Solok berdasarkan Tatib DPRD Kota Solok membidangi Ekonomi dan Keuangan. Mitra Kerja Komisi III ini berdasarkan Keputusan Pimpinan DPRD Kota Solok, salah satunya adalah Dinas Pendapatan dan Pengelolaan Keuangan Daerah (DPPKA) Kota Solok sehingga anggarannya berada dalam DPA DPPKA ketika itu, maka detil anggarannya lebih lanjut dilakukan dengan Satuan Kerja Perangkat Daerah (SKPD) tersebut.

Dalam Dokumen Kebijakan Umum Anggaran (KUA) Kota Solok Tahun 2015 dalam bab tentang Belanja Hibah disebutkan pelaksanaan pemilihan kepala daerah pada Tahun 2015, maka daerah diwajibkan untuk menganggarkan bantuan hibah bagi Komisi Pemlihan Umum (KPU) Daerah dengan mempedomani Undang-Undang Nomor 15 Tahun 2011 tentang Penyelenggara Pemilihan Umum dan Peraturan Menteri Dalam Negeri Nomor 57 Tahun 2009 tentang Pedoman Pengelolaan Belanja Pemilihan Umum Kepala Daerah dan Wakil Kepala Daerah. Pengganggran belanja hibah di dalam Dokumen Prioritas dan Plafon Anggaran Sementara (PPAS) Tahun 2015 disebutkan harus digunakan sesuai dengan persyaratan yang telah ditetapkan dalam Naskah Perjanjian Hibah Daerah (NPHD) antara pemberi hibah dengan penerima hibah. Dalam Dokumen baik dokumen KUA Kota Solok Tahun 2015 dan PPAS Tahun 2015 juga termuat Anggaran Belanja Hibah. Untuk Kota Solok karena keterbatasan anggaran Total Belanja Hibah dialokasikan sebanyak Rp. 12.200.000.000,-Usulan awal yang diajukan oleh KPU Kota Solok sebesar Rp 6.314.851,- (Enam Milyar Tiga Ratus Empat Belas Juta Delapan Ratus Lima Puluh Satu Rupiah) yang diajukan oleh KPU Kota Solok setelah melewati tahap pembahasan dengan DPRD Kota Solok melalui Badan Anggaran yang disetujui adalah sebesar Rp. 3.650.000.000,- (Tiga Milyar Enam Ratus Lima Puluh Juta Rupiah), angka tersebutlah yang menjadi dasar dibuatnya NPHD pada proses selanjutnya.

DPRD Kota Solok telah memainkan fungsinya dalam hal fungsi anggaran, dengan mempunyai kekuasaan untuk membahas, menyetujui, menyepakati dan menetapkan APBD dan Perubahan APBD bersama Kepala Daerah, hal ini juga sesuai dengan fungsi Badan Anggaran DPRD Kota Solok tentang tugas-tugas yang mesti dijalankan yang tercantum dalam Tata Tertib DPRD Kota Solok Nomor 1 Tahun 2014. Jika dirunut dokumen 
perencanaan anggaran awal, setelah terjadi pembahasan dengan TAPD Kota Solok dan sebelum dilakukan pembahasan oleh DPRD Kota Solok Anggaran kebutuhan pelaksanaan Pemilihan Walikota dan Wakil Walikota Kota Solok Tahun 2015 yang lalu adalah sebagai berikut:

Tabel 5.

Dokumen Awal Pelaksanaan Anggaran Pemilihan Walikota dan Wakil Walikota Solok Tahun 2015

\begin{tabular}{|c|c|c|c|}
\hline No & Uraian & Nilai & Jumlah \\
\hline A & Honorarium dan Uang Lembur & & 1.846 .530 .000 \\
\hline 1 & Honorarium & 1.620 .000 .000 & \\
\hline 2 & Uang Lembur & 225.670 .000 & \\
\hline $\mathrm{B}$ & Pengadaan Barang dan Jasa & & 4.468 .321 .050 \\
\hline 1 & $\begin{array}{l}\text { Pengadaan Barang Cetakan dan } \\
\text { Penggandaan }\end{array}$ & 203.791 .100 & \\
\hline 2 & $\begin{array}{l}\text { Perlengkapan Pemungutan dan } \\
\text { Penghitungan suara lainnya }\end{array}$ & 49.729 .450 & \\
\hline 3 & Distribusi PP (Termasuk Bongkar Muat) & 10.445 .000 & \\
\hline 4 & Pemeliharaan & 70.000 .000 & \\
\hline 5 & BBM Kendaraan Roda 4 dan Roda 2 & 39.072 .000 & \\
\hline 6 & Pelayanan Administrasi Perkantoran & 469.723 .000 & \\
\hline 7 & $\begin{array}{l}\text { Sewa Kendaraan roda } 4 \text {, roda } 2 \text { atau } \\
\text { kendaraaan lainnya }\end{array}$ & 58.500 .000 & \\
\hline 8 & Pembentukan PPK, PPS dan KPPS & 36.426 .000 & \\
\hline 9 & Pengelolaan Logistik Pilkada & 49.513 .000 & \\
\hline 10 & Persiapan Pemungutan Suara & 43.963 .500 & \\
\hline 11 & Penerangan/Penyuluhan/Sosialisasi & 655.050 .000 & \\
\hline 12 & $\begin{array}{l}\text { Rapat Kerja/Pelatihan dengan KPU Kota } \\
\text { Solok }\end{array}$ & 124.210 .000 & \\
\hline 13 & Advokasi Hukum & 320.000 .000 & \\
\hline 14 & Rapat Kerja & 130.300 .000 & \\
\hline 15 & Perjalanan Dinas & 701.411 .000 & \\
\hline 16 & Pencalonan & 92.900 .000 & \\
\hline 17 & Pelaksanaan Kegiatan Kampanye & 1.252 .325 .000 & \\
\hline 18 & Proses Penghitungan Suara & 60.902 .000 & \\
\hline 19 & Audit dan Pengumuman Dana Kampanye & 100.000 .000 & \\
\hline \multicolumn{3}{|c|}{ Total } & 6.362 .731 .050 \\
\hline
\end{tabular}

Sumber: KPU Kota Solok.

Berdasarkan hasil pembahasan KPU dengan TAPD Kota Solok, hasil pembahasan terhadap kebutuhan anggaran pelaksanaan Pemilihan Walikota dan Wakil Walikota Solok Tahun 2015 yang lalu adalah sebesar Rp. 6.362.731.050,- (Enam Milyar Tiga Ratus Enam Puluh Dua Juta Tujuh Ratus Tiga Puluh Satu Ribu Lima Puluh Rupiah). Sedangkan anggaran yang disetujui oleh DPRD ketika itu adalah sebesar Rp. 3.650.000.000,- (Tiga Milyar Enam Ratus Lima Puluh Juta Rupiah) yang mengalami rasionalisasi karena keterbatasan dan kemampuan APBD Kota Solok. Angka senilai Rp. 3.650.000.000,- (Tiga Milyar Enam Ratus Lima Puluh Juta Rupiah) inilah yang menjadi dasar dibuatnya NPHD yang pertama antara 
KPU Kota Solok dengan Pemerintah Kota Solok. Sedangkan pada NPHD yang selanjutnya, yang merupakan pembahasan antara KPU Kota Solok dengan TAPD yang masuk ke dalam perubahan anggaran APBD Kota Solok Tahun Anggaran 2017 kembali mengalami revisi dalam Rencana Kerja Anggaran KPU Kota Solok dalam anggaran Pemilihan Walikota dan Wakil Walikota Kota Solok yaitu dengan nilai Rp. 5.401.010.500,- (Lima Milyar Empat Ratus Satu Juta Rupiah Sepuluah Ribu Lima Ratus Rupiah), yang terbagi dalam dua tahun anggaran yaitu pada Tahun Anggaran 2015 sebanyak Rp. 4.813.047.500,- (Empat Milyar Delapan Ratus Tiga Belas Juta Empat Puluh Tujuh Ribu Lima Ratus Rupiah) dan Tahun Anggaran 2016 sebanyak Rp. 587.963.000,- (Lima Ratus Delapan Puluh Tujuh Juta Sembilan Ratus Enam Puluh Tiga Ribu Rupiah). Besaran anggaran inilah yang pada akhirnya dijalankan oleh KPU Kota Solok berdasarkan pembahasan dengan TAPD Kota Solok dengan KPU Kota Solok, tetapi perubahan anggaran tersebut tidak dibahas kembali dengan DPRD Kota Solok.

Sehingga jika kita bandingkan antara besar anggaran yang dibutuhkan dalam penyelenggaraan Pemilihan Walikota dan Wakil Walikota Solok Tahun 2015 yaitu sebesar Rp. 5.401.010.500,- dengan jumlah pemilih yang ada di Kota Solok berdasarkan rekapitulasi yang dilakukan oleh KPU Kota Solok dalam laporannya yaitu sebanyak 46.091, maka didapatkan kebutuhan per satu orang DPT adalah sebesar Rp. 117.181,-. Angka tersebut tidak dapat dikategorikan tinggi atau mahal, karena banyak variabel yang mempengaruhinya diantaranya adalah biaya kampanye dan alat peraga ketika Pilkada Serentak 2015 Gelombang I tersebut hampir semua kebutuhan kampanye kandidat atau kontestasi ditanggung seluruhnya oleh penyelenggara, jumlah penduduk, standar biaya masukan yang berbeda untuk tiap daerah, kondisi tingkat kesulitan geografis dan sebagainya. Hemat penulis Pilkada ini dinilai mahal karena Anggaran Pemilihan Walikota dan Wakil Walikota Solok Tahun 2015 ini juga juga mesti menanggung biaya kampanye seperti ikan media massa, alat peraga kampanye, distribusi alat peraga kampanye dan debat publik yang sangat membutuhkan biaya yang besar. Hal tersebut dilakukan agar terdapat kesetaraan dalam persaingan kontestan yang ikut dalam Pemilihan Walikota dan Wakil Walikota Solok Tahun 2015 tersebut. Hal lain, karena tidak terdapat pendanaan bersama dengan beban kerja yang proporsional antara Provinsi Sumatera Barat dengan Kota Solok dalam melaksanakan Pilkada serentak nasional gelombang pertama ini. Hasil penelitian dan pemahaman penulis penganggaran pemilihan kepala daerah secara serentak nasional yang dilakukan di Kota Solok untuk memilih Walikota dan Wakil Walikota Solok secara prinsip sesuai dengan yang digambarkan oleh Mullins (2007) walaupun dengan kontribusi masing-masing unsur yang berbeda pada fase dalam penganggaran yang beliau kemukakan.

\section{E. PENUTUP}

Hasil analisis penelitian ini menyimpulkan bahwa penganggaran Pemilihan Kepala Daerah secara serentak di Kota Solok Provinsi Sumatera Barat Tahun 2015 telah berdasarkan pada prinsip-prinsip dalam tahapan yang terdapat dalam siklus penganggaran yaitu budget preparation and formulation (persiapan dan formulasi anggaran), dan legislative review and approval (pembahasan dan persetujuan oleh lembaga legislatif). Anggaran Pemilihan Walikota Solok dilakukan oleh tiga aktor utama yaitu KPUD Kota Solok, TAPD, dan DPRD Kota Solok. Turbulensi kebijakan tentang pelaksanaan Pilkada dan Anggaran Pilkada dengan kesiapan dokumen perencanaan daerah dan anggaran Pilkada yang tidak mengganggu siklus anggaran daerah. Dalam Pilkada Serentak Nasional yang terjadi di Sumatera Barat khususnya Pemilihan Walikota Solok tidak terjadi pendanaan bersama karena masih menanggung beban anggaran pelaksanaannya masing-masing. Kegagalan pendanaan bersama antara Pilkada 
Kota Solok dengan Pilgub Sumatera Barat ini menurut penulis karena terlambatnya pelbagai kebijakan yang dikeluarkan oleh pemerintah tentang hal tersebut. Belum terdapatnya anggaran yang proporsional sesuai dengan beban kerja pada Pilkada serentak nasional ini juga dikarenakan belum terdapatnya formula pendanaan Pilkada serentak nasional tersebut. Ditambah lagi, kebijakan tentang penganggaran bersama dalam Pilkada serentak ini keluar ketika proses penganggaran atau siklus anggaran di daerah sudah berjalan pada tahun sebelumnya dan tahapan Pilkada telah dimulai. Regulasi yang berlaku pada saat itu juga membebankan kegiatan kampanye kepada anggaran penyelenggara Pilkada seperti debat publik, bahan kampanyae, alat peraga, dan iklan media massa cetak dan elektronik. Sehingga Pilkada Serentak Nasional yang bertujuan untuk efisiensi anggaran sehingga masih memerlukan banyak perubahan yang mesti dilakukan baik dari sisi regulasi maupun pelaksanaannya dan memerlukan formulasi khusus agar pembagian beban secara proporsional dapat terwujud.

Disain Pilkada ke depan harus segera untuk dirumuskan, karena yang terjadi sekarang baru tahapan menuju pemilu serentak (concurrent election) yang akan menggabungkan pemilihan kepala daerah, DPRD Provinsi dan DPRD kabupaten/kota sehingga terwujudnya pemerintahan daerah yang kongruen dan tidak terbelah. Sehingga sumber pendanaan berasal dari APBN untuk membiayai seluruh pelaksanaan kepala daerah di Indonesia adalah langkah bijak yang mesti diambil ke depan agar anggaran tersebut lebih efisien dan akuntabel dengan cara menyerentakkan pemilu dan memusatkan anggaran serta obyektivitas biaya yang dikeluarkan untuk pendanaan pemilihan menjadi lebih terukur. Ketika rumusan tentang anggaran pemilu serentak ini tidak segera dilahirkan dan diatur dalam peraturan perundangundangan yang berlaku, maka pada Tahun 2027 nanti akan ada 514 Kabupaten/Kota dan 34 Provinsi yang akan membuat NPHD dan betapa kerepotan yang mesti ditanggung karena ada Hibah Pilkada yang kesemuanya akan dilakukan oleh Pemerintah Daerah dan proses evaluasi APBD yang akan dilakukan oleh Kementerian Dalam Negeri.

\section{DAFTAR PUSTAKA}

Anderson, James E. (2006). Public Policy Making. Boston and New York: Houghton Mifflin Company.

Bastian, Indra. (2009). Sistem Perencanaan dan Penganggaran Pemerintah Daerah di Indonesia. Jakarta: Salemba Empat. . (2010). Akuntansi Sektor Publik. Jakarta: Erlangga.

Creswell, John W. (2013). Qualitative Inquiry \& Research Design: Choosing Among Five Approaches. Thousand Oaks, California: SAGE.

Djafar, Muhammad Ridwan. (2006). Politik Anggaran Daerah. Studi tentang proses perumusan kebijakan anggaran dalam penyusunan APBD tahun 2005 di Kabupaten Mamuju Provinsi Sulawesi Barat-Tesis tidak terpublikasi.

Fanloni, Swesti. (2006). Penetapan Alokasi Anggaran Belanja Daerah di Kota Padang. Magister Administrasi Publik. UGM-Yogyakarta. Tesis Tidak terpublikasi.

Gibran, Joan M dan Sekwat, Alex. (2009). Continuing the Search for A Theory of Public Budgeting. Journal of Public Budgeting, Accounting \& Financial, 21 (4), 617-644.

Hanida, Rozidateno Putri., Koeswara, Hendri., Can, Yutris dan Saputra, Hendra. (2011). Analisis Anggaran Belanja Daerah (Studi Terhadap Profil Belanja Kota Solok guna Meningkatkan Fungsi Budgeting, Universitas Andalas, Laporan Penelitian. 
Heivilin, Donna M. Ouverson. (1987). Comparative Study of State Budgeting Principles and Practices. George Washington University. Disertasi tidak terpublikasi.

Henandarto, Itjak. (2009). Pelaksanaan Kebijakan Penyusunan Rencana Kerja Anggaran Kementerian/Lembaga dengan Pejabat Penganggaran Berbasis Kinerja di Departemen Keuangan. Universitas Indonesia-Jakarta. Tesis tidak terpublikasi.

Hermawan, Herman. (2013). Pelaksanaan Fungsi Anggaran DPRD Kota Bekasi: Studi Mengenai Penyusunan APBD Kota Bekasi Tahun 2012. Universitas Indonesia-Jakarta. Tesis tidak terpublikasi.

Heru Setianto, Nugroho. (2004). Implementasi Penyusunan Anggaran Kinerja Berdasarkan Kepmendagri No. 29 Tahun 2002 di Kota Depok. Universitas Indonesia-Jakarta. Tesis tidak terpublikasi.

Hisyam, Akhmad. (2012). Pengalokasian Anggaran Pada Anggaran Pendapatan dan Belanja Daerah Kabupaten Tegal Tahun Anggaran 2009-2011 (Suatu Analisis dengan Pendekatan AlokatifEfisien. Universitas Indonesia-Jakarta. Tesis tidak terpublikasi.

Hoiri, M. Amin. (2014). Implementasi Kebijakan Anggaran Tahun Jamak dalam Pembangunan. Universitas Padjadjaran-Bandung. Disertasi tidak terpublikasi.

Hough, Paul G. (1994). Reforming the Planning, Programming, and Budgeting System in the Department of Defense: A study of Budget Process and Rules. George Mason University-Virginia. Disertasi tidak terpublikasi.

Indrayeni. (2013). Teori, Konsep, dan Aplikasi Akuntansi Sektor Publik. Jakarta: Salemba Empat.

Kestari, Mira. (2011). Analisis Alokasi Anggaran Responsif Gender di Sektor Pendidikan dan Kesehatan pada APBD Kabupaten Bogor Tahun Anggaran 2008-2010. Universitas Indonesia-Jakarta. Tesis tidak terpublikasi.

Koeswara, Hendri., Liesmana, Roza., Hanida, Rozidateno P., Muluk, Saeful. 2011. Proposing an Efficient and Democratic Policy of General Election Budget for Promoting Local Fiscal Autonomy. Jurnal Bisnis dan Birokrasi, 2 (2), 65-77.

Lee, JR, Robert D., Johnson, Ronald W. dan Joyce, Philip G. (2013). Public Budgeting System. Burlington MA: Jones \& Bartlett Learning.

Mardiasmo. (2004). Otonomi dan Manajemen Keuangan Daerah. Yogyakarta: ANDI. . (2009). Akuntansi Sektor Publik. Yogyakarta: ANDI.

Makhya, Syarief. (2012). Formulasi Kebijakan Anggaran Pendapatan dan Belanja Daerah (APBD) Provinsi Lampung. Universitas Padjadjaran-Bandung. Disertasi tidak terpublikasi.

Manapode, Imen Djoli. (2012). Implementasi Kebijakan Anggaran Pendidikan di Kabupaten Kepulauan Talaud. Universitas Padjadjaran-Bandung. Disertasi tidak terpublikasi.

Mikesell, John L. (2007). Fiscal Administration in Local Government:An Overiew. Dalam Local Budgeting. Anwar Shah (ed). Washington: World Bank.

Mullins, R Daniel. (2007). Local Budget Process. Dalam Local Budgeting. Anwar Shah (ed). Washington: World Bank.

Prawoto, Agus. (2011). Pengantar Keuangan Publik. Yogyakarta: BPFE.

Reed, B.J. dan Swain, John W. (1997). Public Finance Administration. Thousands Oaks, California: SAGE.

Rosenbloom, David H. dan Kravchuck, Robert S. (2005). Public Administration: Understanding Management, Politics, and Law. New York: McGraw-Hill. 
Rubin, I. (2000). The politics of Public Budgeting: Getting and Spending, Borrowing and Balancing. Washington, DC: CQ Press.

Ristanto, Anang. (2011). Analisis Implementasi Penyusunan Anggaran Berbasis Kinerja di Lingkungan Sekjen Kemdiknas. Universitas Indonesia-Jakarta. Tesis tidak terpublikasi.

Sanur L, Debora. (2015). Kesiapan Pilkada Serentak 2015. Info Singkat Pemerintahtan Dalam Negeri. Vol. VII No. 14/II/P3DI/Juli/2015.

Shah, Anwar dan Shen, Chunli. (2007). Citizen-Centric Performance Budgeting at Local Level. Dalam Local Budgeting. Anwar Shah (ed). Washington: World Bank.

Seknas Fitra. (2010). Laporan Penelitian Anggaran Pilkada 2010. Jakarta: Seknas Fitra\&TAF.

Suparmoko. (2003). Keuangan Negara: Dalam Teori dan Praktek. Yogyakarta: BPFE.

Yani, Ahmad. (2010). Implementasi Kebijakan Pengelolaan Keuangan Daerah di Kabupaten Bekasi Provinsi Jawa Barat. Universitas Padjadaran-Bandung. Disertasi tidak terpublikasi.

Zaltsman, Teodor Ariel. (2008). The Role of Monitoring and Evaluation in the Budgetary Process: Insigths from a study of Chile's Prformance-Based Budgeting System. New York University-New York. Disertasi tidak terpublikasi. 